\title{
Decoupling of ammonium regulation and $n t c A$ transcription in the diazotrophic marine cyanobacterium Trichodesmium sp. IMS101
}

\author{
Anton F Post ${ }^{1,2}$ Branko Rihtman ${ }^{3}$ and Qingfeng Wang ${ }^{2}$ \\ ${ }^{1}$ The Josephine Bay Paul Center for Comparative Molecular Biology and Evolution, Marine Biological \\ Laboratory, Woods Hole, MA, USA; ${ }^{2}$ The 'H. Steinitz' Marine Biology Laboratory, Interuniversity Institute for \\ Marine Science, Eilat, Israel and ${ }^{3}$ Life Sciences Institute, Hebrew University at Givat Ram, Jerusalem, Israel
}

\begin{abstract}
Nitrogen (N) physiology in the marine cyanobacterium Trichodesmium IMS101 was studied along with transcript accumulation of the $\mathrm{N}$-regulatory gene ntcA and of two of its target genes: napA (nitrate assimilation) and nifH ( $\mathrm{N}_{2}$ fixation). $\mathrm{N}_{2}$ fixation was impaired in the presence of nitrite, nitrate and urea. Strain IMS101 was capable of growth on these combined N sources at $<2 \mu \mathrm{M}$ but growth rates declined at elevated concentrations. Assimilation of nitrate and urea was impaired in the presence of ammonium. Whereas ecologically relevant $\mathrm{N}$ concentrations $(2-20 \mu \mathrm{M})$ suppressed growth and assimilation, much higher concentrations were required to affect transcript levels. Transcripts of nifH accumulated under nitrogen-fixing conditions; these transcript levels were maintained in the presence of nitrate $(100 \mu \mathrm{M})$ and ammonium $(20 \mu \mathrm{M})$. However, nifH transcript levels were below detection at ammonium concentrations $>20 \mu \mathrm{M}$. napA mRNA was found at low levels in both $\mathrm{N}_{2}$-fixing and ammonium-utilizing filaments, and it accumulated in filaments grown with nitrate. The positive effect of nitrate on napA transcription was abolished by ammonium additions of $>200 \mu \mathrm{M}$. This effect was restored upon addition of the glutamine synthetase inhibitor L-methionin-DL-sulfoximine. Surprisingly, ntcA transcript levels remained high in the presence of ammonium, even at elevated concentrations. These findings indicate that ammonium repression is decoupled from transcriptional activation of ntcA in Trichodesmium IMS101.
\end{abstract}

The ISME Journal (2012) 6, 629-637; doi:10.1038/ismej.2011.121; published online 22 September 2011

Subject Category: geomicrobiology and microbial contributions to geochemical cycles

Keywords: cyanobacteria; Trichodesmium; $\mathrm{N}$ assimilation; nitrogen fixation; $n t c A$

\section{Introduction}

Cyanobacteria require nitrogen $(\mathrm{N})$ as an essential macronutrient and they are capable of assimilation of a suite of organic and inorganic $\mathrm{N}$ compounds. Ammonium is the preferred combined $\mathrm{N}$ source for most if not all cyanobacteria. Cells acquire ammonium by diffusive pathways as well as active transport (Boussiba and Gibson, 1991; Herrero et al., 2001). Once inside, it is rapidly incorporated into essential cell components by the enzymes of the glutamine synthetase/glutamate synthase pathway. In the presence of high concentrations of ammonium, cyanobacteria are neither capable of assimilating other $\mathrm{N}$ sources, nor can they engage in $\mathrm{N}_{2}$ fixation and heterocyst development (Flores and Herrero, 1994). Type I glutamine synthetase activities are repressed by ammonium additions (Merida

Correspondence: AF Post, The Josephine Bay Paul Center for Comparative Genomics and Molecular Evolution, Marine Biological Laboratory, 7 MBL Street, Woods Hole, MA 02543, USA.

E-mail: apost@mbl.edu

Received 13 May 2011; revised 3 August 2011; accepted 3 August 2011; published online 22 September 2011 et al., 1991). Ammonium reversibly inhibits nitrate assimilation (Ohmori et al., 1977; Flores et al., 1980). This involves the C-terminus of NrtC-one of the ATPase components of the nitrate transporterand its truncation relieves the ammonium inhibition (Kobayashi et al., 1997). Nitrite uptake by marine Synechococcus WH7803 was repressed by ammonium additions (Lindell et al., 1998). Ammonium also affects the transcription of $\mathrm{N}$ assimilation genes through (de)repression of $n t c A$, a N-regulatory gene. Its gene product, NtcA, is a $24 \mathrm{kD}$ DNA-binding protein that belongs to the cAMP receptor protein (CRP) family of transcriptional activators (VegaPalas et al., 1992; Flores and Herrero, 1994). Freshwater and marine unicellular, non- $\mathrm{N}_{2}$-fixing cyanobacteria show a clear, direct relationship between $n t c A$ expression and low ammonium levels (Frias et al., 1994; Lee et al., 1999; Sauer et al., 1999; Lindell and Post, 2001; Lindell et al., 2005) Marine Synechococcus WH7803 expresses ntcA at basic levels when grown on ammonium. These levels increase to intermediate when exposed to alternative $\mathrm{N}$ sources and maximum transcript levels are attained under N starvation (Lindell and Post, 2001; Lindell et al., 2005). 
Marine diazotrophic cyanobacteria like Cyanothece, UCYN-A, Richellia and Trichodesmium can overcome $\mathrm{N}$ starvation by means of $\mathrm{N}_{2}$ fixation (Capone et al., 1997; Zehr et al., 2001, 2008; Tripp et al., 2010). Rates of $\mathrm{N}_{2}$ fixation by Trichodesmium were not affected on the short term by $\leqslant 1 \mu \mathrm{M}$ ammonium or nitrate, but these rates decreased when these compounds were added at $\geqslant 10 \mu \mathrm{M}$ (Mulholland et al., 2001). Anabaena PCC 7120 and Trichodesmium NIBB 11067 are capable of utilizing combined N compounds (Ohki et al., 1991; Muro-Pastor et al., 2002). Uptake rates of nitrate and urea were low in comparison with those of ammonium, glutamate and mixed amino acids (Mulholland and Capone, 1999; Mulholland et al., 2001). A later report mentioned that $\mathrm{N}_{2}$-fixing filaments of the non-heterocystous Trichodesmium IMS101 release ammonium to the surrounding medium (Mulholland et al., 2001). Uptake rates of ammonium often exceed rates of $\mathrm{N}_{2}$ fixation (Mulholland et al., 2001). Although both organisms thrive in $\mathrm{N}$-depleted environments, $\mathrm{N}$ assimilation is thus not as stringently controlled in Trichodesmium as was found in marine Synechococcus (Lindell and Post 2001; Lindell et al., 1998, 2005). This led us to hypothesize that NtcA control over $\mathrm{N}$ assimilation may be principally different in the non-heterocystous filaments of Trichodesmium spp.

The role of $n t c A$ in $\mathrm{N}$ assimilation by diazotrophic cyanobacteria is far less understood. Two putative binding sites were identified upstream of $n t c A$ in Anabaena PCC 7120 (Muro-Pastor et al., 2002), but they were not positioned at $40.5 \mathrm{nt}$ as in most NtcA-activated promoters (Luque et al., 1994; Herrero et al., 2001). NtcA is required for heterocyst formation but its requirement for expression of the nif genes is not well established (Frias et al., 1994; Ramasubramanian et al., 1994; Muro-Pastor et al., 1999). Studies of the nifHDK operon transcription in Anabaena PCC 7120 and Trichodesmium IMS101 do not identify NtcA recognition sequences (Ramasubramanian et al., 1994; Chen et al., 1998). NtcA binds only weakly to these promoter regions (Ramasubramanian et al., 1994), but it is required for nif gene expression in Anabaena (Frias et al., 1994). Transcript levels of $n t c A$ and nif genes were inversely proportional in the unicellular diazotroph Cyanothece sp. (Bradley and Reddy, 1997). Nitrate and urea at 20 and $2 \mathrm{mM}$, respectively, did not inhibit nifHDK transcript accumulation in Trichodesmium (Dominic et al., 1998). The nitrate transport in Trichodesmium IMS101 involves a permease of the Major Facilitator Superfamily (Wang et al., 2000), different from the nrt $A B C D$-encoded transporter in Anabaena (Frias et al., 1997; Flores et al., 2005). The nirA operon of the latter has distinct promoter elements but lacks a clearly defined NtcAbinding motif (Wang et al., 2000). Here we report on the cloning, sequencing and transcriptional regulation of the ntcA gene from Trichodesmium
IMS101 as well as its role in the utilization of $\mathrm{N}$ sources other than ammonium.

\section{Materials and methods}

\section{Cultivation}

Cultures of Trichodesmium sp. strain IMS101 were maintained in 50 and $150 \mathrm{ml}$ Nalgene bottles (Rochester, NY, USA) using the seawater-based TMV medium that lacks a combined $\mathrm{N}$ source (Prufert-Bebout et al., 1993). Cultures were maintained at $24{ }^{\circ} \mathrm{C}$ and a $12 / 12 \mathrm{~h} \mathrm{light/dark} \mathrm{cycle} \mathrm{with}$ light provided by 'warm-white' fluorescent tubes at an incident irradiance of $20 \mu \mathrm{mol}$ quanta $\mathrm{m}^{-2} \mathrm{~s}^{-1}$. Culture bottles were swirled twice a day to avoid adhesion of filaments to the walls. Growth experiments were carried out in basic TMV medium as well as in TMV medium amended with one of the following $\mathrm{N}$ sources: $\mathrm{NaNO}_{3}, \mathrm{NaNO}_{2}, \mathrm{NH}_{4} \mathrm{Cl}$ or urea (Merck Chemicals, Darmstadt, Germany; highest purity grade). Growth was monitored from both chlorophyll $a$ concentrations and filament counts (Stihl et al., 2001).

\section{Nitrate uptake}

To $250 \mathrm{ml}$ cultures at mid-exponential phase treated with $0,2,20$ or $200 \mu \mathrm{M}$ of $\mathrm{NH}_{4} \mathrm{Cl}, \mathrm{NaNO}_{3}$ was added to a final concentration of $10 \mu \mathrm{M}$. Samples $(1 \mathrm{ml})$ were taken at discrete intervals over a $6 \mathrm{~h}$ timespan, filtered over a $0.2 \mu \mathrm{m}$ membrane filter (Poretics Inc., Livermore, CA, USA) and diluted in $9 \mathrm{ml} 0.2 \mu \mathrm{m}$ filtered sea water. The diluted samples were kept at $4{ }^{\circ} \mathrm{C}$ until analysis. After passage over a Cd-column, nitrate was determined as nitrite on a flow injection nutrient analyzer (QuickChem, LACHAT Instruments, Loveland, CO, USA). The detection limit was $10 \mathrm{nM}$ of nitrite.

\section{Ammonium uptake}

To $100 \mathrm{ml}$ mid-log phase cultures grown with 0 , 1 , 10,100 and $1000 \mu \mathrm{M}$ of $\mathrm{NO}_{3}^{-}, \mathrm{NH}_{4} \mathrm{Cl}$ was added to a final concentration of $10 \mu \mathrm{M}$. Ammonium was determined on $2 \mathrm{ml}$ samples taken at discrete intervals over a $6 \mathrm{~h}$ timespan. Samples were filtered through a $0.2 \mu \mathrm{m}$ membrane filter (Poretics Inc.), followed by the addition of orthophtaldehyde (Holmes et al., 1999). Sample fluorescence was determined on a Hoeffer Dynaquant fluorimeter (Holliston, MA, USA) $3 \mathrm{~h}$ after reagent addition and ammonium concentrations (with a $10 \mathrm{nM}$ detection limit) were calculated using a $\mathrm{NH}_{4} \mathrm{Cl}$ standard curve.

\section{DNA analyses}

Genomic DNA of Trichodesmium sp. strain IMS101 was extracted following the protocol published in West and Scanlan (1999). Genomic DNA was used as a template in PCR amplification with degenerate primers 1f and $4 \mathrm{r}$ used for amplification of the N-regulatory gene ntcA (Lindell et al., 1998). The 
$n t c A$ amplicon was ${ }^{32} \mathrm{P}$ labeled using a KinaseMax oligolabeling kit (Invitrogen) and ${ }^{32} \mathrm{P}-\alpha$ ATP, and hybridized to EcoRI-SpeI digests of Trichodesmium genomic DNA. A positive $\sim 9.0 \mathrm{~kb}$ genomic fragment was identified by Southern blotting. A partial library was constructed by ligation of the $8.0-10.0 \mathrm{~kb}$ fragments into pBluescript $\mathrm{KS}+$ plasmid following EcoRI-SpeI digestion of genomic DNA, and subsequent transformation into Escherichia coli host strain $\mathrm{DH} 5 \alpha$. A positive clone that contained a $9.0 \mathrm{~kb} n t c A$ fragment was identified by screening the library and was submitted to sequence analysis with primer hopping using the Dye Terminator Cycle Sequencing procedure and a model ABI 377 automated sequencer (PE-Biosystems Inc., Carlsbad, CA, USA).

NtcA expression and purification

E. coli Rosetta cells were grown on LB medium up to optical density at $600 \mathrm{~nm}$ of 0.6 and then induced with IPTG $(0.4 \mathrm{mM})$ for $2 \mathrm{~h}$. Cells were harvested by centrifugation and resuspended with 1/10 of the original volume in lysis buffer (10 mM Hepes pH 7.5, $150 \mathrm{mM} \mathrm{NaCl}, 3.4 \mathrm{mM}$ EDTA, $0.005 \%$ Tween-20, $1 \mathrm{mM} \quad$ PMSF, $25 \mu \mathrm{g} \mathrm{ml}^{-1} \quad$ DNAse, $0.2 \mathrm{mg} \mathrm{ml}^{-1}$ lysozyme, $10 \mathrm{mM} \mathrm{MgCl}_{2}$ and 1:200 dilution of a protease inhibitor cocktail (Sigma, St Louis, MO, USA; P8465). The cells were disrupted using a French Press at 900 psi. The extract was centrifuged for $15 \mathrm{~min}$ at $10000 \mathrm{~g}$. The supernatant containing the MBP-NtcA fusion protein was then mixed with amylase beads, and incubated for $2 \mathrm{~h}$ at $4{ }^{\circ} \mathrm{C}$ with gentle agitation. The mixture was centrifuged (3500 r.p.m. for $3 \mathrm{~min}$ at $4{ }^{\circ} \mathrm{C}$ ). Pellets containing the beads were passed through eight cycles of washes with column buffer (10 mM Hepes pH 7.5, $150 \mathrm{mM}$ $\mathrm{NaCl}, 3.4 \mathrm{mM}$ EDTA and $0.005 \%$ Tween-20), followed by centrifugation. Finally, the MBP-NtcA protein was eluted to exhaustion using $10 \mathrm{mM}$ maltose in the column buffer. Purity of eluted fraction was tested by sodium dodecyl sulfatepolyacrylamide gel electrophoresis.

\section{PCR amplification of promoter regions}

Promoter regions of cyanobacterial ntc $A$ and $g \ln A$ (glutamine synthetase) were inspected for putative NtcA-binding sites. Each of the promoter regions was PCR amplified using specific primers to yield DNA fragments of $100-200 \mathrm{bp}$ in size. PCR amplicons were purified with a Promega kit (Wizard, SV gel and PCR clean-up system) and submitted to DNA sequence analysis of both strands. PCR products of $780 \mathrm{bp}$ were cut out from the 1\% agarose gels, purified with Promega (Madison, WI, USA) 'Wizard SV Gel and PCR clean-up system' kit and submitted to DNA sequence analysis of both strands.

\section{Electrophoretic mobility shift assays}

PCR products (20-60 ng) were incubated at $30^{\circ} \mathrm{C}$ for 20 min with different concentrations of MBP-NtcA purified protein ( $0-3 \mu \mathrm{g}$ protein), in binding buffer (25 mM Tris-HCl pH 8.0, $12 \%$ glycerol, $60 \mathrm{mM} \mathrm{KCl}$ and $4 \mathrm{~mm}$ spermidine), in $25 \mu \mathrm{l}$ final volume. At the end of the incubation, $12.5 \mu \mathrm{l}$ of $60 \%$ sucrose was added and the samples were separated on nondenaturing $6 \%$ polyacrylamide gels at $4{ }^{\circ} \mathrm{C}$ and $15 \mathrm{~mA}$ with TAE (40 mM Tris-acetate, $1 \mathrm{mM}$ EDTA) containing $1 \mathrm{mM} \mathrm{MgCl}_{2}$ as running buffer. The gels were stained with Vista-Green (Amersham, Piscataway, NJ, USA), and diluted 10000 times in TAE buffer for $20 \mathrm{~min}$. The gels were washed with TAE buffer and scanned using a phosphorimager (Fuji FLA300) at $473 \mathrm{~nm}$ emission.

\section{RNA extraction}

Samples $(250 \mathrm{ml})$ of Trichodesmium culture were harvested halfway through the light period and filtered onto $5 \mu \mathrm{m}$ pore size, polycarbonate membrane filters (Poretics). Filters were immediately transferred into $1 \mathrm{ml}$ of ice-cold lysis buffer $(100 \mathrm{mM}$ LiCl, $30 \mathrm{~mm}$ Na-EDTA, 1\% w/v SDS, $50 \mathrm{~mm}$ Tris-HCl $\mathrm{pH}=8.0$ ) and stored at $-70^{\circ} \mathrm{C}$. Samples were thawed at room temperature and heated at $65^{\circ} \mathrm{C}$ for $5 \mathrm{~min}$, extracted once with an equal volume of acid phenol $\left(\mathrm{pH}=4.5\right.$, pre-warmed at $\left.65^{\circ} \mathrm{C}\right)$, followed by phenol/chloroform and chloroform extraction. After isopropanol precipitation and ethanol washes, samples were dried at room temperature for $30 \mathrm{~min}$ and redissolved in sterile distilled water. Precipitates were then treated with RQ1 RNase-Free DNase (Promega) at $37^{\circ} \mathrm{C}$ for $1 \mathrm{~h}$, followed by phenol/chloroform extraction, $100 \%$ ethanol precipitation and $70 \%$ ethanol washes. The DNAse-treated RNA pellet was dissolved in $100 \mu \mathrm{l}$ of RNAse-free water, and submitted to serial dilution. RNA samples were aliquoted to avoid contamination and RNA degradation during repeated thawing and freezing of samples.

\section{RT-PCR}

Semiquantitative reverse transcriptase-PCR (RTPCR) protocols that compare relative transcript levels of target genes with those of housekeeping genes (including $16 \mathrm{~S}$ or $18 \mathrm{~S}$ rRNA) also use the internal control to titrate the exact amount of total RNA added to each reaction (Nicoletti and SassyPrigent, 1996; Ogretmen et al., 1998; Wang et al., 2002). The expression of N-regulated genes, ntcA, $n a p A$ and nifH, was studied using this semiquantitative RT-PCR method with minor modifications. Sequences of forward and reverse primers and the expected size of PCR products are listed in Table 1. RT-PCR was performed using the Access RT-PCR System (Promega). A typical RT-PCR reaction of $25 \mu \mathrm{l}$ contained $1 \mu \mathrm{l} \mathrm{MgSO}_{4} \quad(25 \mathrm{~mm}), \quad 0.5 \mu \mathrm{l}$ dNTPs $(10 \mathrm{mM}), 2.5 \mu \mathrm{l}$ Buffer $(10 \times), 1 \mu \mathrm{l}$ of forward and reverse primers $(25 \mu \mathrm{M}), 0.5 \mu \mathrm{l}$ of AMV (Avian Myeloblastosis Virus) reverse transcriptase (Promega), $0.5 \mu \mathrm{l}$ of Tfl DNA polymerase, 1-10 $\mu \mathrm{l}$ of 
Table 1 Sequence of primers and expected product sizes used in the reverse transcriptase-PCR (RT-PCR) expression studies

\begin{tabular}{|c|c|c|c|}
\hline Gene & Primer & Sequence & Size of product \\
\hline $16 S^{\mathrm{a}}$ & $\begin{array}{l}359 \mathrm{~F} \\
1313 \mathrm{R}\end{array}$ & $\begin{array}{l}5^{\prime} \text {-GGGGAATYTTCCGCAATGGG-3' } \\
5^{\prime} \text {-CTTCACGTAGGCGAGTTGCAGC-3' }\end{array}$ & $1.0 \mathrm{~kb}$ \\
\hline nifH & $\begin{array}{l}\text { nif-1F } \\
\text { nif-1R }\end{array}$ & $\begin{array}{l}\text { 5'-CTTAAACGCTAAAGCTCAAACTAC-3' } \\
5^{\prime} \text {-CACGGATAGGCATTGCAAATCC-3' }{ }^{\prime}\end{array}$ & $275 \mathrm{bp}$ \\
\hline napA & $\begin{array}{c}\operatorname{nir}-9 \mathrm{~F} \\
\text { nir-10R }\end{array}$ & $\begin{array}{l}\text { 5'-GCTGCACTCTATGGTGTG-3' } \\
5^{\prime} \text {-GCAGGCAGCATAGAAACTACTGG-3' }\end{array}$ & $405 \mathrm{bp}$ \\
\hline$n t c A$ & $\begin{array}{l}\text { ntc-1F } \\
\text { ntc-4R }\end{array}$ & $\begin{array}{l}5^{\prime} \text {-CCAGGAGATCCTGCCGAGCGTGTC-3' } \\
5^{\prime} \text {-CCAATTGCTTCTGCAATTGCTTGGTG-3' }\end{array}$ & $445 \mathrm{bp}$ \\
\hline
\end{tabular}

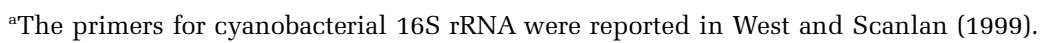

total RNA in proper dilution and RNase free water to $25 \mu \mathrm{l}$. To minimize tube-to-tube variation, Reaction buffer, $\mathrm{MgSO}_{4}$, dNTP and water were assembled in advance as a master mix and aliquoted, immediately before each RT-PCR reaction, followed by the addition of enzymes and primers, and RNA template. RT-PCR reactions were run on a PTC-200 Peltier Thermal Cycler (MJ Research, Inc., Waltham, MA, USA) with the following conditions: incubation at $48{ }^{\circ} \mathrm{C}$ for $1 \mathrm{~h}$, denaturation at $94^{\circ} \mathrm{C}$ for $2 \mathrm{~min}$, followed by Taq polymerase addition and 26-30 cycles of $94{ }^{\circ} \mathrm{C}$ for $1 \mathrm{~min}, 45-55^{\circ} \mathrm{C}$ for $1 \mathrm{~min}$ and $68{ }^{\circ} \mathrm{C}$ for $1 \mathrm{~min} 20 \mathrm{~s}$, and then an extra step of elongation at $68^{\circ} \mathrm{C}$ for $5 \mathrm{~min}$. Annealing temperature was $45{ }^{\circ} \mathrm{C}$ for napA amplification, $50{ }^{\circ} \mathrm{C}$ for $16 \mathrm{~S}$ rRNA and $55{ }^{\circ} \mathrm{C}$ for nifH and ntcA amplifications. For the purpose of quantification, template amounts ranging from $3 \mathrm{pg}$ to $300 \mathrm{ng}$ of total RNA were tested over 28 cycles to find suitable template concentration that permit exponential amplification for each of the target genes. The amount of total RNA was titrated based on the 16S rRNA gene as internal standard, and transcript levels for each gene were normalized to the transcript level of 16S rRNA in the same sample. A parallel RT-PCR negative control without AMV reverse transcriptase was carried out for each sample to ascertain absence of DNA contamination. Products of RT-PCR were run on $1.2 \%$ agarose/EtBr gels, viewed under ultraviolet light and analyzed by densitometry with Quantitiy One (Bio-Rad, Hercules, CA, USA). All experiments were replicated independently for 2-4 times.

\section{Results}

Nitrogen physiology

Although marine Trichodesmium spp. are known as abundant diazotrophs, they do have a capability to utilize inorganic $\mathrm{N}$ sources as well as organic $\mathrm{N}$ compounds like urea (Goering et al., 1966; Saino and Hattori, 1978). Trichodesmium IMS101 grew at a faster rate in TMV medium amended with $2 \mu \mathrm{M}$ ammonium, nitrate or urea than in TMV medium lacking a combined N source (Figure 1a). However, growth was retarded or even fully inhibited at $4 \mu \mathrm{M}$ ammonium and $20 \mu \mathrm{M}$ nitrate, respectively
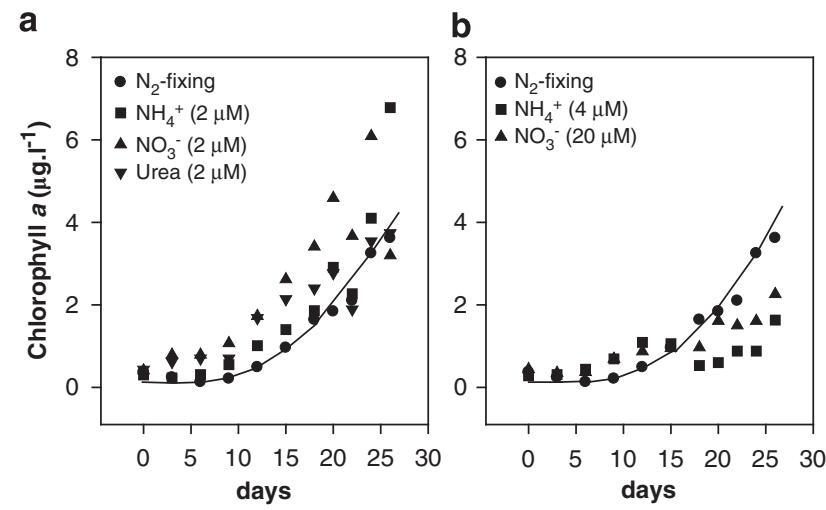

Figure 1 Diazotrophic growth (solid line) of Trichodesmium sp. IMS101 as compared with growth in the presence of low $(2 \mu \mathrm{M})$ concentrations of nitrate and ammonium (a) and at elevated $(4-20 \mu \mathrm{M})$ concentrations of these $\mathrm{N}$ sources (b).

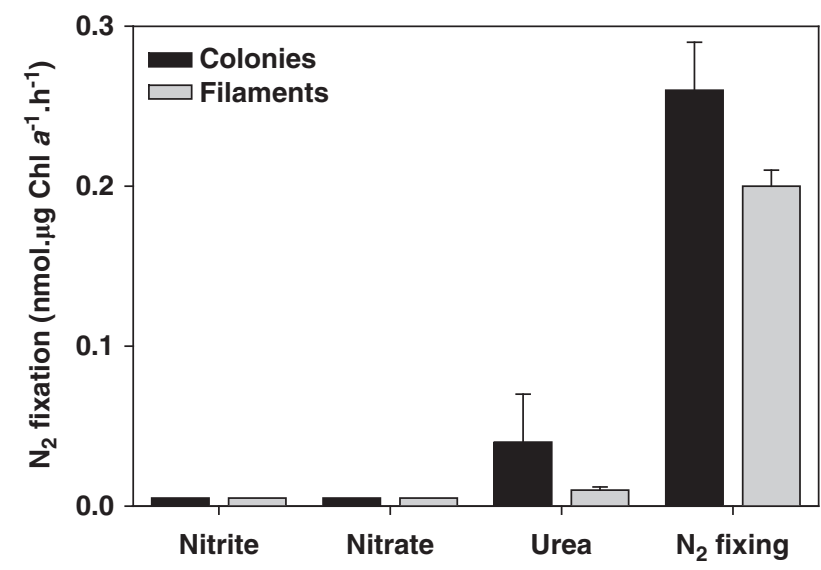

Figure 2 Ethylene reduction activities of Trichodesmium sp. IMS101 cultures grown on different $\mathrm{N}$ sources: nitrate $(10 \mu \mathrm{M})$, nitrite $(10 \mu \mathrm{M})$ and urea $(5 \mu \mathrm{M})$ and in the absence of combined $\mathrm{N}$ ( $\mathrm{N}_{2}$ fixing).

(Figure 1b), and $40 \mu \mathrm{M}$ urea (data not shown). $\mathrm{N}_{2}$ fixation by Trichodesmium IMS101 was also affected by $\mathrm{N}$ source. $\mathrm{N}_{2}$ fixation was much slower in Trichodesmium cultures with urea than in $\mathrm{N}$-deplete controls (Figure 2). $\mathrm{N}_{2}$ fixation was fully inhibited in the presence of $10 \mu \mathrm{M}$ nitrate or $10 \mu \mathrm{M}$ nitrite. 
Nitrate utilization in turn was affected by the presence of ammonium (Figure 3). Nitrate acquisition was progressively inhibited with ammonium additions of increasing concentration (Figure 3a). Conversely, ammonium assimilation was not affected by nitrate and identical acquisition rates of ammonium were determined in the concentration range of 0 to $1 \mathrm{mM}$ of this oxidized $\mathrm{N}$ source (Figure 3b). Thus, Trichodesmium preferentially assimilated ammonium over nitrate, and nitrate assimilation over $\mathrm{N}_{2}$ fixation. Ammonium addition immediately downregulated nitrate assimilation and $\mathrm{N}_{2}$ fixation. In the non- $\mathrm{N}_{2}$-fixing Synechococcus WH7803, ntcA transcription is below detection when ammonium concentrations exceed $1 \mu \mathrm{M}$, and transcript levels are upregulated in nitrate-grown cells and become maximal under N-deplete conditions (Lindell and Post 2001; Lindell et al., 1998, 2005). It has been reported that ambient ammonium accumulates to $\sim 2 \mu \mathrm{M}$ in $\mathrm{N}_{2}$-fixing (=N-deplete) cultures of Trichodesmium IMS101 (Mulholland et al., 2001), thus raising questions about the mechanisms of ammonium control over $\mathrm{N}$ assimilation and $\mathrm{N}_{2}$ fixation in this organism. This led us to study aspects of transcription patterns for the $\mathrm{N}$-regulatory gene, ntcA, in Trichodesmium.

\section{Identification of ntcA}

We PCR amplified a $449 \mathrm{bp}$ product of the Trichodesmium IMS101 ntcA gene and used it to screen a clone library of EcoRI-SpeI-digested genomic DNA fragments. A positive clone of $9.5 \mathrm{~kb}$ molecular size was identified and sequenced (Genbank accession AF382392). Figure 4 shows the open reading frames (ORFs) deduced from the primary DNA sequence.
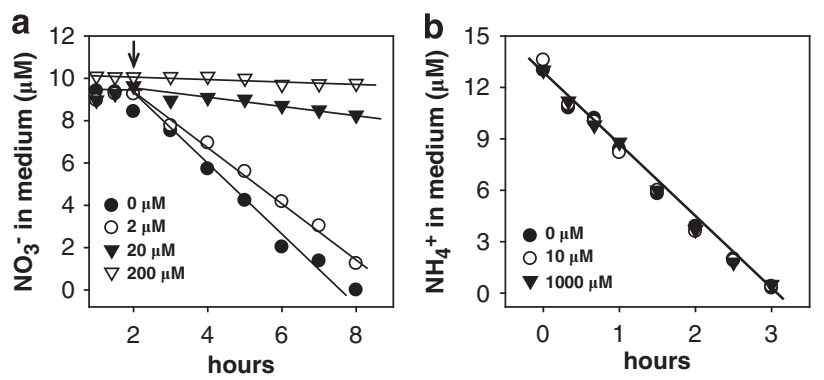

Figure 3 Effect of different ammonium additions (arrow) on nitrate uptake in nitrate-grown cultures of Trichodesmium IMS101 (a) and the effect of different nitrate concentrations on ammonium uptake by such cultures (b).

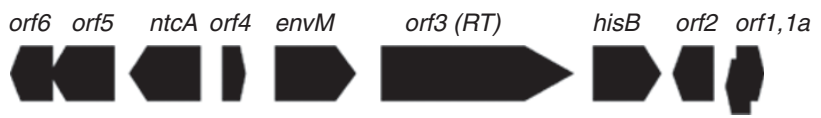

Figure 4 Gene arrangement of a $9 \mathrm{~kb}$ genomic DNA fragment of Trichodesmium IMS101 carrying the N-regulatory gene ntcA and its flanking regions. Block arrows denote the individual ORFs with their direction of transcription.
Upstream of $n t c A$ we identified $f a b I$ ( $=e n v H$, enoyl carrier reductase) and hisB (imidazole-glycerol phosphate dehydrogenase). Interestingly, an ORF located between these genes showed $>60 \%$ aminoacid identity with reverse transcriptase of group II introns. Finally, the $3^{\prime}$ end of the $9.5 \mathrm{~kb}$ fragment consisted largely of non-coding DNA with the exception of an ORF with some similarity to transposons/transposases. The ntcA gene was found near the $5^{\prime}$ end of the fragment and was similar to ntcA of Nostoc azollae (E-value 3e-120), Nostoc punctiforme (E-value 1e-119) and Nostoc PCC 7120 (E-value 8e-109). Two ORFs (ORF5 and ORF6) immediately downstream of $n t c A$ were in the same orientation as ntcA (Figure 4). ORF5 was first identified in Anabaena PCC 7120 (Ramasubramanian et al., 1994, 1996) and ntcA-ORF5 form a conserved gene pair in nearly all cyanobacteria (AF Post, unpublished data). As no clear promoter elements were identifiable upstream of ORF5, we studied the transcription of ntcA and ORF5 by RT-PCR. Attempts to amplify an RT product that linked the $3^{\prime}$ end of $n t c A$ with the $5^{\prime}$ end of ORF5 were unsuccessful. However, Figure 5 shows that both genes were co-transcribed in $\mathrm{N}_{2}$-fixing filaments of Trichodesmium IMS101. We identified a putative NtcA-binding motif CGTG..N $\mathrm{N}_{8} .$. AACT starting at $96 \mathrm{nt}$ upstream of the $n t c A$ initiation codon in Trichodesmium, thus setting the stage for autoregulation of $n t c A$ transcription. A second putative, atypical binding site (AGTA... N $_{9}$..TACA) was identified starting $307 \mathrm{nt}$ upstream of the initiation codon. Overexpressed Prochlorococcus MED4 NtcA retarded DNA fragments with the ntcA promoter regions of Prochlorococcus MED4, but also that of Synechococcus WH7803 (Figure 6, lanes 5 and 6). Additions of NtcA to DNA with the $n t c A$ and $g \ln A$ promoters of the diazotrophs Trichodesmium IMS101 and Anabaena PCC 7102 (lanes 1-4) showed significant retardation of these fragments. This retardation was least pronounced for PntcA of Trichodesmium where DNA binding caused a smear with only a faint product at higher molecular weight (Figure 6).

Transcriptional regulation

Semiquantitative RT-PCR was employed to assess $n t c A$ transcript levels in Trichodesmium IMS101 under different $\mathrm{N}$ treatments. Figure 7 shows that

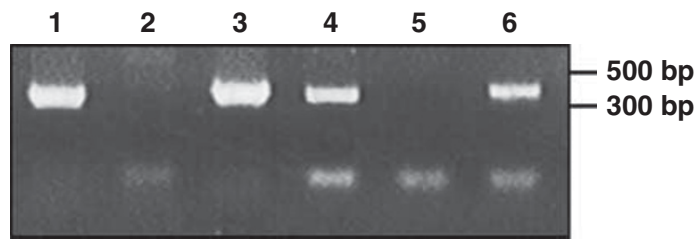

Figure 5 Co-transcription of ntcA (lanes 1-3) and ORF5 (lanes 4-6) in $\mathrm{N}_{2}$-fixing filaments of Trichodesmium IMS101. PCR amplicons were derived from genomic DNA (lanes 1 and 4) and total RNA before (lanes 2 and 5) and after (lanes 3 and 6) reverse transcriptase treatment. 
$n t c A$ RNA was readily amplified from total RNA of $\mathrm{N}_{2}$-fixing filaments after RT. $\mathrm{NH}_{4}^{+}$additions of $2-2000 \mu \mathrm{M}$ enhanced ntcA transcript levels in Trichodesmium after $1 \mathrm{~h}$ of incubation (Figure $7 \mathrm{a}$ ). Similarly, $\mathrm{NO}_{3}^{-}$additions of $0.5-1000 \mu \mathrm{M}$ caused an

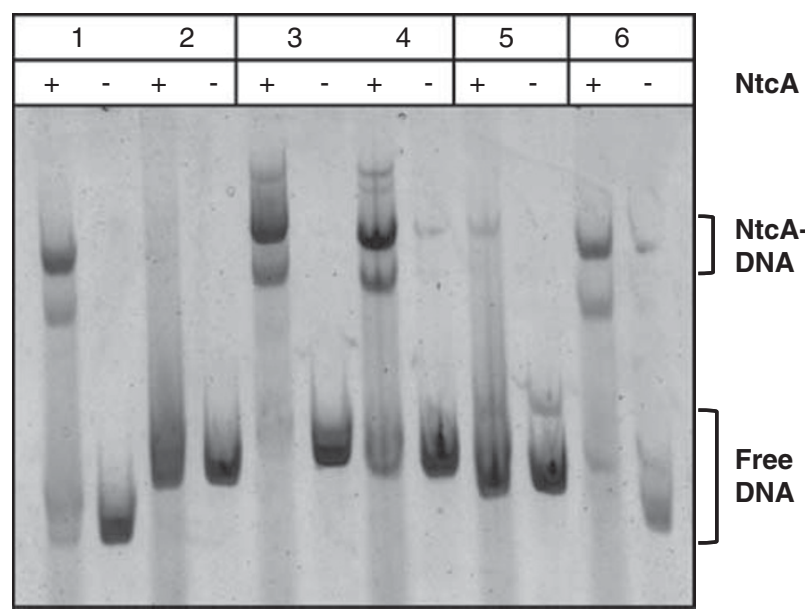

Figure 6 NtcA binding to N-regulated promoters in electrophoretic mobility shift assay (EMSA) experiments with overexpressed, maltose-column purified NtcA of Prochlorococcus strain MED4. (Lanes 1 and 2) PglnA and PntcA of Trichodesmium IMS101, (lanes 3 and 4) PglnA and PntcA of Anabaena PCC 7120 (lane 5) PntcA of Synechocococcus WH7803, and (lane 6) PntcA of Prochlorococcus MED4.

a
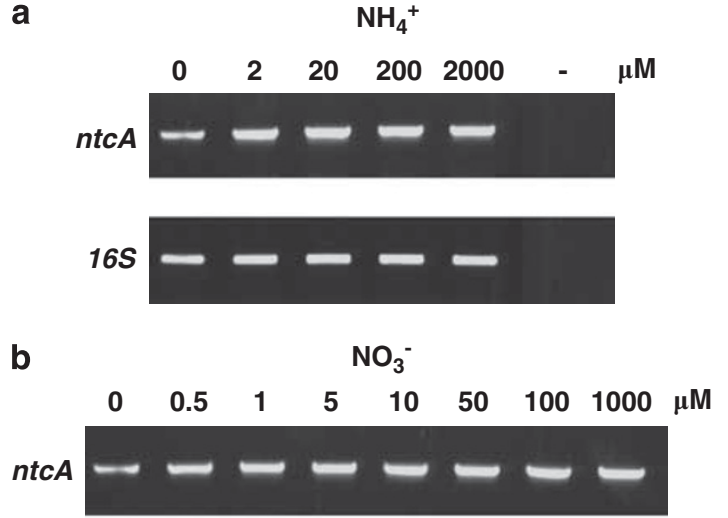

$16 S$
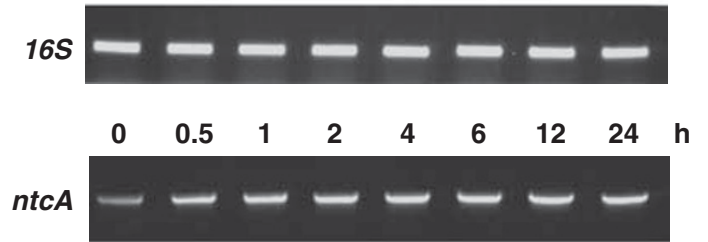

$16 S$

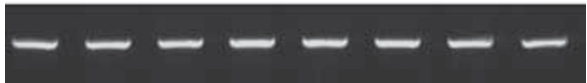

Figure 7 Levels of ntcA transcripts in Trichodesmium IMS101 filaments after different ammonium treatments for $1 \mathrm{~h}(\mathbf{a})$, at different concentrations of nitrate for $1 \mathrm{~h}$ and for different times with $100 \mu \mathrm{M}$ nitrate (b). Total RNA was titrated to equal amounts using 16S rRNA as internal control. approximate $40 \%$ increase in $n t c A$ transcript level (Figure $7 \mathrm{~b}$ ). The effect of $\mathrm{N}$ source on $n t c A$ transcription was not of a transient nature and transcript levels stayed high for at least $24 \mathrm{~h}$ (Figure 7c).

$\mathrm{N}_{2}$-fixing filaments of Trichodesmium IMS101 accumulated high levels of nifH transcript as expected (Figure 8). However, similar transcript levels of nifH were found in the presence of nitrate $(100 \mu \mathrm{M})$ or ammonium $(2-20 \mu \mathrm{M})$. Such filaments have significantly lower nitrogen-fixation rates (Figure 2) and utilize the combined $\mathrm{N}$ source. At ammonium concentrations in excess of $20 \mu \mathrm{M}$, nifH transcript levels declined and no nifH transcripts were detected at $\mathrm{NH}_{4}^{+}$concentrations of $\geqslant 200 \mu \mathrm{M}$ (Figure 8).

Nitrate utilization requires the expression of the nitrate transporter encoded by nap $A$, which forms part of the nirA operon in Trichodesmium IMS101 (Wang et al., 2000). Both $\mathrm{N}_{2}$-fixing and ammoniumutilizing filaments contained low levels of napA transcripts (Figure 9a), as compared with the levels found under nitrate nutrition (Figure 9b). However, the nitrate effect on napA expression was counteracted by addition of ammonium. Transcript levels of napA declined sharply when ammonium was

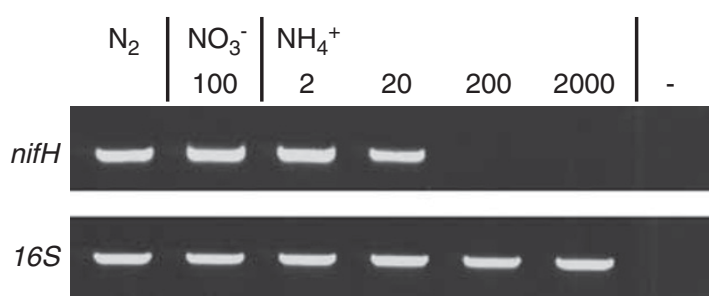

Figure 8 nifH transcript levels in Trichodesmium IMS101 filaments cultured in $\mathrm{N}_{2}$-fixing condition, in $100 \mu \mathrm{M} \mathrm{NO}_{3}^{-}$or in $\mathrm{NH}_{4}^{+}$of different concentrations. The amount of total RNA of different samples was titrated to the same level using housekeeping 16S rRNA gene as internal control as shown in the down row of each panel. The results shown are representative of at least two independent experiments.

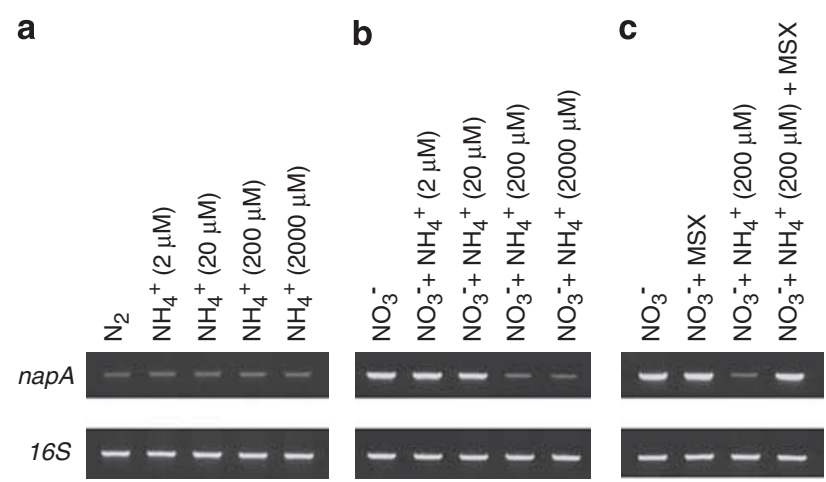

Figure 9 Levels of napA transcript in Trichodesmium IMS101 filaments $1 \mathrm{~h}$ following the addition of different concentrations of ammonium (a), with different combinations of ammonium with $100 \mu \mathrm{M} \mathrm{NO}-$ for $1 \mathrm{~h}(\mathbf{b})$ and (c) with different combinations of nitrate $(100 \mu \mathrm{M})$, ammonium (200 and $2000 \mu \mathrm{M})$ and MSX $(100 \mu \mathrm{M})$. 
present—alongside nitrate-at $\geqslant 200 \mu \mathrm{M}$ (Figure 9b), whereas $2-20 \mu \mathrm{M}$ additions did not affect transcript levels. These findings indicate that ammonium repressed the transcription of nifH and napA, but did not affect $n t c A$ expression. In order to establish whether nitrate-induced nap $A$ expression was controlled by ammonium repression or nitrate stimulation, we studied napA expression in the presence of $100 \mu \mathrm{M}$ L-methionin-DL-sulfoximine (MSX), an inhibitor of glutamine synthase activity. Figure 9c shows that MSX treatment allowed for full expression of nap $A$ in nitrate-grown filaments of Trichodesmium in the presence of ammonium, whereas napA expression in control experiments was suppressed.

\section{Discussion}

Nitrogen utilization

The marine diazotrophic cyanobacterium Trichodesmium IMS101 utilized nitrate, urea and ammonium similar to previous reports (Ohki et al., 1991; Mulholland and Capone, 1999; Mulholland et al., 2001). Growth on combined N was sustained at low concentrations $(\leqslant 2 \mu \mathrm{M})$ only and $\mathrm{N}_{2}$-fixation rates were suppressed at combined $\mathrm{N}$ concentrations of $\geqslant 5 \mu \mathrm{M}$. Ammonium repressed both $\mathrm{N}_{2}$ fixation and nitrate assimilation at ecologically relevant concentrations. Similarly, micromolar concentrations of nitrate and nitrite inhibited $\mathrm{N}_{2}$ fixation. These inhibitory actions establish a hierarchy in which Trichodesmium filaments prefer ammonium over nitrate before they resort to $\mathrm{N}_{2}$ fixation. This hierarchy was not observed in the transcriptional regulation of $\mathrm{N}$ genes in Trichodesmium IMS101. Whereas ammonium repressed the transcription of key genes in nitrate utilization $(\operatorname{nap} A)$ and $\mathrm{N}_{2}$ fixation (nifH), nitrate additions failed to repress nifH transcript levels. Surprisingly, ammonium did not repress the transcription of the N-regulatory gene $n t c A$, and its mRNA accumulated to high levels, even in the presence of $2-2000 \mu \mathrm{M}$ ammonium. In Synechococcus WH7803, ntcA transcript levels dropped below detection when ammonium concentrations exceed $1 \mu \mathrm{M}$ (Lindell and Post, 2001; Lindell et al., 2005).

\section{Ammonium repression}

Ammonium availability is usually considered the key factor in $\mathrm{N}$-adaptive responses through its control over ntcA transcription (Herrero et al., 2001). The use of the glutamine synthetase inhibitor MSX indicated that metabolized (as opposed to ambient) ammonium suppressed the transcription of $\mathrm{N}$ genes in the Trichodesmium filaments, similar to our findings in marine Synechococcus (Lindell and Post, 2001; Lindell et al., 2005). This is consistent with the concept that $\alpha$-oxoglutarate accumulates and acts as the NtcA activator molecule when ammonium supplies are limiting
(Muro-Pastor et al., 2001; Tanigawa et al., 2002). NtcA-binding affinity to its DNA targets is enhanced by $\alpha$-oxoglutarate (Vazquez-Bermudez et al., 2002). The high ntc $A$ transcript levels at $>2 \mu \mathrm{M}$ ammonium would be consistent with high $\alpha$-oxoglutarate levels in Trichodesmium. Intracellular levels of $\alpha$-oxoglutarate ranged between 100 and 1600 pmol per colony (equivalent to 3-200 fmol per cell) over the course of a diel cycle (Mulholland and Capone, 1999). This suggests that $\alpha$-oxoglutarate might be available in sufficient amounts to continuously activate NtcA in Trichodesmium, especially among the high light-exposed surface populations with high rates of photosynthesis. Such populations have $\mathrm{N}_{2}$-fixing capacity and release ammonium into the environment (Mulholland and Capone, 1999; Mulholland et al., 2001). In order to sustain $\mathrm{N}_{2}$-fixation and nifHDK transcription in an NtcAdependent manner, they would have to counteract ammonium repression with high cellular levels of $\alpha$-oxoglutarate.

\section{Transcriptional regulation}

Autoregulation of $n t c A$ transcription requires NtcAbinding upstream of its own gene. We identified $n t c A$ and its neighboring genes on a $9.5 \mathrm{kB}$ genomic fragment in Trichodesmium IMS101. The DNA sequence of this fragment is identical to that found in the complete genome sequence (Genbank accession NC_008312) that was determined subsequently. The genome carries a CRP-like transcriptional activator (locus tag Tery-1557) that was predicted to control the transcription of nifB and nifX-K1-W (see http://regprecise.lbl.gov/RegPrecise). This genome further contains a single ntcA copy (Tery-2023) with a predicted regulon of 18 genes/operons. The NtcA regulon contains ntcB (Tery-4333), which encodes a transcriptional activator of the LysR family that is required for nitrate assimilation (Aichi and Omata, 1997; Frías et al., 2000; Flores et al., 2005). Interestingly, this NtcA regulon prediction suggests that $n t c A$ transcription is not autoregulated. Two putative NtcA-binding sites upstream of the $n t c A$ start codon were identified in this study. These sites are degenerate variants of the consensus-binding site and they were weakly bound by Prochlorococcus NtcA. Interestingly, we found that the same, heterologous NtcA bound strongly to the Anabaena ntcA promoter region, whereas it interacts only weakly binds with its native NtcA (Ramasubramanian et al., 1994). $\mathrm{N}$-induced transcription start points for ntcA have been identified at -49 and $-180 \mathrm{nt}$ in Anabaena PCC 7120 (Olmedo-Verd et al., 2008), a configuration similar to that observed in Trichodesmium. NtcA is further required for development of $\mathrm{N}_{2}$ fixation in Anabaena PCC 7120 (Muro-Pastor et al., 1999), but it is not certain that NtcA activates nifHDK transcription. No correlation was observed between $n t c A$ transcript levels and that of nifHDK in 
Cyanothece BH68K (Bradley and Reddy, 1997). Moreover, nifHDK transcripts of Trichodesmium IMS101 show a clear diel pattern, whereas those of $n t c A$ do not (Chen et al., 1998). Transcription of $n t c A$ occurs from both constitutive and induced transcription start points in Synechococcus spp. and thus yields two transcript populations, the latter one regulated by NtcA (Luque et al., 1994; Lindell et al., 1998). The ntcA expression pattern with high transcript levels in the presence of ammonium as presented here for Trichodesmium is also encountered in the $\mathrm{N}_{2}$ fixers Cyanothece and Anabaena (Ramasubramanian et al., 1996; Bradley and Reddy, 1997). The latter produces three different transcripts, two of which seem to originate from an atypical promoter that involves NtcA binding (Ramasubramanian et al., 1996). Thus, ntcA may be involved in the development of nitrate utilization as its expression is high both in nitrate-grown Trichodesmium IMS101 (this study) and in Cyanothece BH68K (Bradley and Reddy, 1997). The upstream region of the nir operon (which includes the reductase genes and the nitrate transporter napA) in Trichodesmium was shown to have promoter elements (Wang et al., 2000), but lacks a well-defined NtcA-binding site. However, enhanced transcription of napA overcame ammonium repression in the presence of the glutamine synthetase inhibitor MSX, consistent with NtcA regulation in Synechococcus spp. (Suzuki et al., 1993; Lindell and Post, 2001; Tanigawa et al., 2002; Lindell et al., 2005). Not all regulatory aspects of NtcA are known in diazotrophic cyanobacteria. These may include post-transcriptional regulation, different modes of interaction with promoter regions of $\mathrm{N}$ genes and conformational change in NtcA protein. Whereas this remains to be addressed in future studies, our results show unequivocally that ammonium repression and ntcA transcription are uncoupled in the globally important marine diazotroph Trichodesmium sp.

\section{Acknowledgements}

We are grateful to Ruty Gotlieb, Efrat Meeder and Sheba Solomon for assistance in the nitrogen physiology experiments. The research was sponsored by the Red Sea Program Grant 03F0151A by the German Ministry for Education, Science, Research and Technology (BMBF) and the Israel Science Foundation Grant No. 131/05.

\section{References}

Aichi M, Omata T. (1997). Involvement of NtcB, a LysR family transcription factor, in nitrite activation of the nitrate assimilation operon in the cyanobacterium Synechococcus sp, strain PCC 7942. J Bacteriol 179: 4671-4675.

Boussiba S, Gibson J. (1991). Ammonia translocation in cyanobacteria. FEMS Microbiol Lett 88: 1-14.
Bradley RL, Reddy KJ. (1997). Cloning, sequencing and regulation of the global nitrogen regulator gene $n t c A$ in the unicellular diazotrophic cyanobacterium Cyanothece sp. strain BH68K. J Bacteriol 179: 4407-4410.

Capone DG, Zehr JP, Paerl HW, Bergman B, Carpenter EJ. (1997). Trichodesmium, a globally significant marine cyanobacterium. Science 276: 1221-1229.

Chen YB, Dominic B, Mellon MT, Zehr JP. (1998). Circadian rhythm of nitrogenase gene expression in the diazotrophic filamentous non heterocystous cyanobacterium Trichodesmiumsp strain IMS101. J Bacteriol 180: 3598-3605.

Dominic B, Chen YB, Zehr JP. (1998). Cloning and transcriptional analysis of the nifHDK genes of Trichodesmium sp. IMS101 reveals stable nifD, nifDK and nifK transcripts. Microbiology 144: 3359-3368.

Flores E, Frías JE, Rubio LM, Herrero A. (2005). Photosynthetic nitrate assimilation in cyanobacteria. Photosynth Res 83: 117-133.

Flores E, Guerrero MG, Losada M. (1980). Short-term ammonium inhibition of nitrate utilization by Anacystis nidulans and other cyanobacteria. Arch Microbiol 128: 137-144.

Flores E, Herrero A. (1994). Assimilatory nitrogen metabolism and its regulation. In: Bryant DA (ed) The Molecular Biology of Cyanobacteria. Kluwer Academic Publisher: Dordrecht, The Netherlands, pp 487-517.

Frias JE, Flores E, Herrero A. (1994). Requirement of the regulatory protein NtcA for the expression of nitrogen assimilation and heterocyst development genes in the cyanobacterium Anabaena sp. Mol Microbiol 14: 823-832.

Frias JE, Flores E, Herrero A. (1997). Nitrate assimilation gene cluster from the heterocyst-forming cyanobacterium Anabaena sp. strain PCC 7120. J Bacteriol 179: 477-486.

Frías JE, Flores E, Herrero A. (2000). Activation of the Anabaena nir operon promoter requires both NtcA (CAP family) and NtcB (LysR family) transcription factors. Mol Microbiol 38: 613-625.

Goering JJ, Dugdale RC, Menzel DW. (1966). Estimates of in situ rates of nitrogen uptake by Trichodesmium sp. in the tropical Atlantic Ocean. Limnol Oceanogr 11: $614-620$.

Herrero A, Muro-Pastor AM, Flores E. (2001). Nitrogen control in cyanobacteria. J Bacteriol 183: 411-425.

Holmes RM, Aminot A, Kerouel R, Hooker BA, Peterson BJ. (1999). A simple and precise method for measuring ammonium in marine and freshwater ecosystems. Can J Fish Aquat Sci 56: 1801-1808.

Kobayashi M, Rodriguez R, Lara C, Omata T. (1997). Involvement of the $\mathrm{C}$ terminal domain of an ATPbinding subunit in the regulation of the ABC-type nitrate/nitrite transporter of the cyanobacterium $S y$ nechococcus sp. strain PCC 7942. J Biol Chem 272: 27197-27201.

Lee HM, Vazquez-Bermudez F, Tandeau de Marsac N. (1999). The global nitrogen regulator NtcA regulates transcription of the signal transducer $\mathrm{P}_{\mathrm{II}}(\mathrm{GlnB})$ and influences its phosphorylation level in response to nitrogen and carbon supplies in the cyanobacterium Synechococcus sp. strain PCC 7942. J Bacteriol 181: 2697-2702.

Lindell D, Padan E, Post AF. (1998). Regulation of ntcA expression and nitrite uptake in the marine Synechococcus sp. strain WH 7803. J Bacteriol 180: 1878-1886. 
Lindell D, Penno S, Al-Qutob M, David E, Korpal T, Lazar B et al. (2005). Expression of the N-stress response gene ntcA reveals N-sufficient Synechococcus populations in the oligotrophic northern Red Sea. Limnol Oceanogr 50: 1932-1944.

Lindell D, Post AF. (2001). Ecological aspects of $n t c A$ gene expression and its use as an indicator of the nitrogen status of marine Synechococcus spp. Appl Environ Microbiol 67: 3340-3349.

Luque I, Flores E, Herrero A. (1994). Molecular mechanism for the operation of nitrogen control in cyanobacteria. EMBO J 13: 2862-2869.

Merida A, Candeau P, Florencio FJ. (1991). Regulation of glutamine synethetase activity in the unicellular cyanobacterium Synechocystis sp. strain PCC 6803 by the nitrogen source: effect of ammonium. J Bacteriol 173: 4095-4100.

Mulholland MR, Capone DG. (1999). Nitrogen fixation, uptake and metabolism in natural and cultured populations of Trichodesmium spp. Mar Ecol Prog Ser 188: 33-49.

Mulholland MR, Ohki K, Capone DG. (2001). Nutrient control and nitrogen uptake and metabolism by natural populations and cultures of Trichodesmium (cyanobacteria). J Phycol 37: 1001-1009.

Muro-Pastor AM, Valladares A, Flores E, Herrero A. (2002). Mutual dependence of the expression of the cell differentiation regulatory protein HetR and the global nitrogen regulator NtcA during heterocyst development. Mol Microbiol 44: 1377-1385.

Muro-Pastor MI, Reyes JC, Florencio FJ. (2001). Cyanobacteria perceive nitrogen status by sensing intracellular 2-oxoglutarate levels. J Biol Chem 276: 38320-38328.

Muro-Pastor MI, Valladares A, Flores E, Herrero A. (1999). The hetC gene is a direct target of the NtcA transcriptional activator in cyanobacterial heterocyst development. J Bacteriol 181: 6664-6669.

Nicoletti A, Sassy-Prigent C. (1996). An alternative quantitative polymerase chain reaction method. Anal Biochem 236: 229-241.

Ogretmen B, McCauley MD, Safa AR. (1998). Molecular mechanisms of loss of $\beta 2$-microglubulin expression in drug-resistant breast cancer sublines and its involvement in drug resistance. Biochemistry 37: 11679-11691.

Ohki K, Zehr JP, Falkowski PG, Fujita Y. (1991). Regulation of nitrogen-fixation by different nitrogen sources in the marine non-heterocystous cyanobacterium Trichodesmium sp. NIBB1067. Arch Microbiol 156: 335-337.

Ohmori M, Ohmori K, Strotmann H. (1977). Inhibition of nitrate uptake by ammonia in a blue-green alga, Anabaena cylindrica. Arch Microbiol 114: 225-229.

Olmedo-Verd E, Valladares A, Flores E, Herrero A, MuroPastor AM. (2008). Role of two NtcA-binding sites in the complex ntcA gene promoter of the heterocystforming cyanobacterium Anabaena sp. strain PCC 7120. J Bacteriol 190: 7584-7590.

Prufert-Bebout L, Paerl HW, Lassen C. (1993). Growth, nitrogen fixation, and spectral attenuation in cultivated Trichodesmium species. Appl Environ Microbiol 59: $1367-1375$.
Ramasubramanian TS, Wei T-F, Golden JW. (1994). Two Anabaena sp. strain PCC 7120 DNA-binding factors interact with vegetative cell- and heterocyst-specific genes. J Bacteriol 176: 1214-1223.

Ramasubramanian TS, Wei T-F, Oldham AK, Golden JW. (1996). Transcription of the Anabaena sp. strain PCC 7120 ntcA gene: multiple transcripts and NtcA binding. J Bacteriol 178: 922-926.

Saino T, Hattori A. (1978). Diel variation in nitrogen fixation by a marine blue-green alga, Trichodesmium thiebautii. Deep Sea Res 25: 1259-1263.

Sauer J, Margit G, Forchhammer K. (1999). Nitrogen starvation in Synechococcus PCC 7942: involvement of glutamine synthetase and NtcA in phycobiliprotein degradation and survival. Arch Microbiol 172: 247-255.

Stihl A, Sommer U, Post AF. (2001). Alkaline phosphatase activities among populations of the colony-forming, diazotrophic cyanobacterium Trichodesmium (Cyanobacteria) in the Red Sea. J Phycol 62: 310-317.

Suzuki I, Sugiyama T, Omata T. (1993). Primary structure and transcriptional regulation of the gene for nitrite reductase from the cyanobacterium Synechococcus PCC 7942. Plant Cell Physiol 34: 1311-1320.

Tanigawa R, Shirokane M, Maeda S, Omata T, Tanaka K, Takahashi H. (2002). Transcriptional activation of NtcA-dependent promoters of Synechococcus sp. PCC 7942 by 2-oxoglutarate in vitro. Proc Natl Acad Sci USA 99: 4251-4255.

Tripp JH, Bench SR, Turk KA, Foster RA, Desany BA, Niazi F et al. (2010). Metabolic streamlining in an open-ocean nitrogen-fixing cyanobacterium. Nature 464: 90-94.

Vazquez-Bermudez MF, Herrero A, Flores E. (2002). 2-Oxoglutarate increases the binding affinity of the NtcA (nitrogen control) transcription factor for the Synechococcus glnA promoter. FEBS Lett 512: 71-74.

Vega-Palas MA, Herrero A, Flores E. (1992). NtcA, a global nitrogen regulator from the cyanobacterium Synechococcus that belongs to the CRP family of bacterial regulators. Mol Microbiol 6: 1853-1859.

Wang Q, Li H, Post AF. (2000). The nitrate assimilation genes of the marine diazotrophic cyanobacterium Trichodesmium sp. strain WH9601. J Bacteriol 182: 1764-1767.

Wang Q, Liu H, Szaniszlo PJ. (2002). Compensatory expression of five chitin synthase genes, a response to stress stimuli, in Wangiella (Exophiala) dermatitides, a melanized fungal pathogen of humans. Microbiology 148: 2811-2817.

West N, Scanlan DJ. (1999). Niche-partitioning of Prochlorococcus populations in a stratified water column in the eastern North Atlantic Ocean. Appl Environ Microbiol 65: 2585-2591.

Zehr JP, Bench SR, Carter BJ, Hewson I, Niazi F, Shi T et al. (2008). Globally distributed uncultivated oceanic $\mathrm{N}_{2}$-Fixing cyanobacteria lack oxygenic Photosystem II. Science 322: 1110-1112.

Zehr JP, Waterbury JB, Turner PJ, Montoya JP, Omoregie E, Steward GF et al. (2001). Unicellular cyanobacteria fix $\mathrm{N}_{2}$ in the subtropical North Pacific Ocean. Nature 412: 635-638. 